Studia nad Autorytaryzmem i Totalitaryzmem 43, nr 2

Wrocław 2021

https://doi.org/10.19195/2300-7249.43.2.24

\author{
KRZYSZTOF HORUBSKI \\ ORCID: 0000-0003-3062-6015 \\ Uniwersytet Wrocławski \\ krzysztof.horubski@uwr.edu.pl
}

\title{
Problem zamówień publicznych w PRL
}

Słowa kluczowe: zamówienia publiczne, gospodarka centralnie planowana, gospodarka nakazowo-rozdzielcza, dyskryminacja przedsiębiorców prywatnych, umowa jako prawna forma działania administracji, przetargowe i bezprzetargowe tryby zawierania umów.

\section{THE PROBLEM OF PUBLIC PROCUREMENT IN THE POLISH PEOPLE'S REPUBLIC}

\begin{abstract}
The article characterises selected legal solutions applied in the process of public contract award in the realities of the nationalised centrally-planned economy in the times of the Polish People's Republic. In the study, manifestations of discrimination of private businesses in the access to public contracts are presented. Such discrimination was one of the foundations for the legislation applicable at the time. The article also highlights other features of legal acts of statutory rank governing contracts awarded by state-owned organisational units, such as the fragmented nature of their regulations, including the omission of regulations governing the procedure of reaching an agreement and executing a contract. This allowed formulating conclusions about the merely superficial role of the provisions on supplies, services, and works for state entities and the fundamental inability of these regulations to play the role attributed to public procurement in the market economy, consisting in deploying the mechanism of competition between entrepreneurs for cost-efficiencies in public spending.
\end{abstract}

Keywords: public procurement, public contract award, command-and-quota system, centrally controlled economy, discrimination of private entrepreneurs, contract as a legal form of administration, tender and non-tender procedures for concluding contracts.

\section{Wprowadzenie}

Instytucja prawna zamówień publicznych, będąca reżimem prawnym odpłatnego nabywania dóbr i usług przez podmioty publiczne, jawi się obecnie jako niezbędny element ustroju gospodarczego opartego na zasadach gospodarki

Studia nad Autorytaryzmem i Totalitaryzmem 43, nr 2, 2021

(C) for this edition by CNS 
rynkowej. Prawo zamówień publicznych stanowi bowiem konsekwencję odniesienia prawa podstawowego do wolności gospodarczej oraz powinności państwa tworzenia warunków do rozwoju konkurencji między przedsiębiorcami ${ }^{1}$, do występowania przez jednostki organizacyjne szeroko rozumianego państwa $\mathrm{w}$ charakterze nabywców oferowanych na rynku dóbr i usług. Z powyższym stwierdzeniem koresponduje założenie o związaniu podmiotów publicznych prawem publicznym (zasadami prawa publicznego) także wtedy, gdy działają w formach właściwych prawu prywatnemu lub zapożyczonych (wzorowanych) na prywatnoprawnych formach działania. Związanie to trafnie w poglądach niemieckiej doktryny prawa administracyjnego określa się jako brak możliwości „ucieczki w prawo prywatne" (niem. Flucht ins Privatrecht) ${ }^{2}$.

Prawo zamówień publicznych jako prawo publiczne ${ }^{3}$ ma za zadanie urzeczywistniać, w swym zakresie normowania, zasady równego traktowania oferentów (wykonawców) oraz ochrony konkurencji ${ }^{4}$. Powoduje to, że ten zespół unormowań powinien obejmować reguły prawne „wymuszające” na podmiotach publicznych możliwie szerokie otwieranie dostępu do udzielanych zamówień, zarówno pod względem podmiotowym, jak i przedmiotowym. W związku z tym konkurencyjne sposoby zawierania umów w prawie zamówień publicznych, w szczególności mające charakter przetargowy, wpisują się w model społecznej gospodarki rynkowej jako porządku gospodarczego, w którym zaspokajanie potrzeb społecznych odbywa się głównie, choć oczywiście nie wyłącznie, w wyniku aktywności przedsiębiorców prywatnych.

Oparte na powyższych założeniach prawo zamówień publicznych tworzy rynek zamówień publicznych (rynek nabywcy publicznego), stanowiący, obok rynku nabywców prywatnych, istotny element gospodarki rynkowej. Natomiast w ramach ustroju gospodarczego innego niż oparty na zasadach gospodarki rynkowej, kwestie znaczenia oraz treści podstawowych rozwiązań prawnych odpłatnego nabywania dóbr i usług przez podmioty publiczne muszą kształtować się w znacznym stopniu odmiennie, niż ma to miejsce we wskazanym modelu gospodarczym. Treścią rozważań niniejszego artykułu będą wybrane zagadnienia zamówień publicznych w ustroju gospodarki centralnie planowanej (upaństwowionej), w postaci jaka była urzeczywistniana w okresie Polskiej Rzeczypospolitej Ludowej. Punktem odniesienia dla tej tematyki będzie kwestia odrębności (swoistości) rozwiązań, które

1 Zob. art. 5, art. 20, art. 22 Konstytucji Rzeczypospolitej Polskiej z dnia 2 kwietnia 1997 roku, Dz.U. z 1997 r. Nr 78, poz. 483 ze zm.

2 Zob. M. Burgi, Die künftige Bedeutung der Freiheitsgrundrechte für staatliche Verteilungsentscheidungen, [w:] Wirtschaftsverfassung und Vergaberecht - Der Verfassungsrechtliche Rahmen der Auftrags- und Konzessionsvergabe, red. M. Bugenberg, P. Huber, R. Streinz, Stuttgart 2011, s. 29-30; H. Maurer, Ogólne prawo administracyjne. Allgemeines Verwaltungsrecht, Wrocław 2003, s. 43.

3 Zob. R. Szostak, Zakres i struktura prawa zamówień publicznych, „Kwartalnik. Prawo Zamówień Publicznych" 2013, nr 4, s. 15-17.

4 Zob. art. 16 ustawy z dnia 11 września 2019 roku — Prawo zamówień publicznych, Dz.U. z 2019 r. poz. 2019 ze zm. 
możemy określać mianem prawa zamówień publicznych, w ramach gospodarki planowej $\mathrm{PRL}^{5}$, na tle rozwiązań typowych dla prawa zamówień publicznych jako elementu ustroju gospodarczego społecznej gospodarki rynkowej.

\section{Zamówienia publiczne a gospodarka planowa (upaństwowiona)}

Prawo zamówień publicznych jako zespół unormowań służących nabywaniu przez podmioty sektora publicznego dóbr i usług zasadniczo od podmiotów prywatnych jest niewątpliwie koncepcją nieadekwatną w odniesieniu do założeń systemu gospodarki centralnie planowanej (sterowanej), wywodzącego się z ideologii komunistycznej, w szczególności zaś kluczowego dla niej komponentu zakładającego możliwie szeroką eliminację własności prywatnej w funkcjonowaniu społeczeństwa i gospodarki. Model gospodarki planowej (nakazoworozdzielczej) zakłada, docelowo, istnienie gospodarki upaństwowionej, w ramach której to organizacja państwowa jako dysponent środków produkcji, w tym nieruchomości wykorzystywanych na cele produkcyjne, ponosi odpowiedzialność za zaopatrzenie społeczeństwa oraz własnych struktur w dobra i usługi. W takim systemie zasadniczo nie ma potrzeby ochrony takich, właściwych gospodarce rynkowej, wartości jak wolność działalności gospodarczej czy swoboda konkurencji przedsiębiorców, bowiem to państwo, działając poprzez różnorakie jednostki organizacyjne (na przykład przedsiębiorstwa państwowe) ma być, w ogólności, podmiotem organizującym i wykonującym działalność gospodarczą (,hegemonem gospodarczym"). Wobec tego w okresie powojennym w Polsce Ludowej wraz z postępami upaństwawiania gospodarki i wdrażania ustroju gospodarki centralnie planowanej odpowiednim zmianom i dostosowaniu musiała podlegać regulacja prawna odpłatnego nabywania dóbr i usług przez państwowe jednostki organizacyjne. W tym kontekście należy wskazać, że w okresie II Rzeczypospolitej Polskiej wprowadzono regulację zamówień publicznych właściwą dla uwarunkowań gospodarki rynkowej, zakładającą zaspokajanie istotnej części potrzeb publicznych przez przedsiębiorców prywatnych ${ }^{6}$ konkurujących o możliwość zawierania kontraktów z publicznymi nabywcami. Ustawa z dnia 15 lutego 1933 roku

${ }^{5}$ R. Szostak wskazuje, że okresie nakazowo-rozdzielczego sterowania gospodarką w PRL doszło wręcz do zaniku obecności pojęcia zamówień publicznych w języku prawnym oraz prawniczym. Nie zmienia to jednak faktu, że funkcjonowała regulacja prawna działań jednostek państwowych polegających na zawieraniu umów, w celu uzyskiwania świadczeń majątkowych dla zaspokojenia potrzeb takich jednostek; idem, Regulacja prawa zamówień publicznych $w$ Polsce w ujęciu historycznym, „Prawo Zamówień Publicznych. Kwartalnik” 2012, nr 4, s. 26-27.

${ }^{6}$ Zob. § 2-3 rozporządzenia Rady Ministrów z dnia 29 stycznia 1937 roku o dostawach i robotach na rzecz Skarbu Państwa, samorządu oraz instytucyj prawa publicznego, Dz.U. z 1937 r. $\mathrm{Nr}$ 13, poz. 92; dalej: rozporządzenie z 1937 roku. 
o dostawach i robotach na rzecz Skarbu Państwa, samorządu oraz instytucyj prawa publicznego ${ }^{7}$, a także wydane do niej rozporządzenie z 1937 roku przewidywały możliwość ubiegania się o zamówienia, przede wszystkim, przez przedsiębiorców krajowych, dopuszczając do rynku zamówień publicznych także przedsiębiorców zagranicznych, zrejestrowanych zgodnie z prawem polskim i dysponujących „wydzielonym kapitałem” na obszarze Polski. Odnośne unormowania wprowadzały preferencje krajowe poprzez wskazanie, że „dostawy i roboty powinny być wykonywane przy użyciu sił krajowych i surowców oraz wszelkich wyrobów pochodzenia krajowego, względnie o ile ich produkcja w kraju jest niewystarczająca $\mathrm{z}$ użyciem tych surowców i wyrobów, w takim stopniu, aby produkcja ich została całkowicie wykorzystana" (art. 2 ust. 2 ustawy z 1933 roku). Wskazane akty prawne normowały istotne aspekty proceduralne udzielania zamówień publicznych, czyniąc najbardziej konkurencyjny tryb przetargu nieograniczonego podstawowym sposobem dochodzenia do zawarcia umowy o zamówienie publiczne ${ }^{8}$.

Ustawa z 1933 roku formalnie obowiązywała do roku 1948, kiedy to uchwalono ustawę o dostawach, robotach i usługach na rzecz Skarbu Państwa, samorządu oraz niektórych kategorii osób prawnych ${ }^{9}$. Ustawa ta zmierzała do dostosowania reżimu prawnego zakupów publicznych do równolegle wprowadzanych zasad gospodarki planowej oraz postępującego upaństwowienia działalności gospodarczej. W tym kontekście warto zauważyć, że w 1946 roku uchwalono ustawę o przejęciu na własność państwa podstawowych gałęzi gospodarki narodowej ${ }^{10}$. Z kolei w 1947 roku został wydany dekret o planowej gospodarce narodowej ${ }^{11}$, a także ustanowiono akty prawne, będące podstawą dla szeroko zakrojonych działań, mających na celu redukcję prywatnej działalności handlowej w ramach tak zwanej bitwy o handel ${ }^{12} \mathrm{w}$ związku z podnoszonym „zagrożeniem” odrodzenia

7 Ustawa z dnia 15 lutego 1933 roku o dostawach i robotach na rzecz Skarbu Państwa, samorządu oraz instytucyj prawa publicznego, Dz.U. z 1933 r. Nr 19, poz. 127 ze zm.; dalej: ustawa z 1933 roku.

${ }^{8}$ Zob. $\S 16$ ust. 2 rozporządzenia z 1937 roku.

${ }^{9}$ Ustawa z dnia 18 listopada 1948 roku o dostawach, robotach i usługach na rzecz Skarbu Państwa, samorządu oraz niektórych kategorii osób prawnych (Dz.U. z 1948 r. Nr 63, poz. 494); dalej: ustawa z 1948 roku.

10 Ustawa z dnia 3 stycznia 1946 roku o przejęciu na własność Państwa podstawowych gałęzi gospodarki narodowej, Dz.U. z 1946 r. Nr 3, poz. 17 ze zm.

11 Dekret z dnia 1 października 1947 roku o planowej gospodarce narodowej, Dz.U. z 1947 r. $\mathrm{Nr}$ 64, poz. 373.

12 Zob. ustawa z dnia 2 czerwca 1947 roku o obywatelskich komisjach podatkowych i lustratorach społecznych, Dz.U. z 1947 r. Nr 43, poz. 218 ze zm.; ustawa z dnia 2 czerwca 1947 roku o zezwoleniach na prowadzenie przedsiębiorstw handlowych i zawodowe wykonywanie czynności handlowych, Dz.U. z 1947 r. Nr 43, poz. 220 ze zm.; ustawa z dnia 2 czerwca 1947 roku o zwalczaniu drożyzny i nadmiernych zysków w obrocie handlowym, Dz.U. z 1947 r. Nr 43, poz. 218 ze zm. 
się kapitalizmu ${ }^{13}$. Widać więc wyraźnie, że ustawa z 1948 roku wpisywała się w ciąg działań zmierzających do transformacji gospodarki powojennej Polski do modelu typowego dla państw tworzącego się bloku sowieckiego.

\section{Wybrane aspekty regulacji zamówień publicznych w prawodawstwie Polski Ludowej}

W świetle ustawy z 1948 roku główną zasadą, jaką powinien kierować się państwowy nabywca (zamawiający) było dążenie do zawarcia umowy z innym podmiotem (jednostką organizacyjną) o charakterze państwowym. Odnośny akt prawny przewidywał tylko dwa sposoby kontraktowania - tryb bezprzetargowy oraz pisemny tryb przetargowy. Pierwszy z nich był dostępny wyłącznie dla umów zawieranych pomiędzy podmiotami państwowymi zobowiązanymi do stosowania ustawy a przedsiębiorstwami znajdującymi się pod dominującym wpływem administracji państwowej, wskazanymi w art. 5 ust. 1.

Drugi z odnośnych trybów miał wprawdzie charakter konkurencyjny, ale skorzystanie z niego, a więc stworzenie możliwości zawarcia umowy z podmiotem prywatnym, z założenia należało do rzadkości. Przetarg nieograniczony na zamówienie państwowe był dopuszczalny jedynie wtedy, gdy przedmiot zamówienia nie był objęty działalnością przedsiębiorstw kontrolowanych przez państwo albo jeżeli takie przedsiębiorstwa nie podejmowały się wykonania zamówienia $\mathrm{w}$ ilości i terminach zakładanych przez zamawiającego (art. 6 ust. 1 ustawy z 1948 roku). Oznaczało to konieczność poszukiwania, w tak zwanym trybie bezprzetargowym, potencjalnych wykonawców zamówienia spośród jednostek gospodarczych wymienionych $\mathrm{w}$ art. 5, czyli spośród między innymi przedsiębiorstw państwowych, przedsiębiorstw pod zarządem państwowym, przedsiębiorstw państwowo-spółdzielczych czy centrów spółdzielczo-państwowych. Dopiero brak efektu takich poszukiwań otwierał możliwość skorzystania z trybu przetargu nieograniczonego. Dodatkowo zgodnie z art. 6 ust. 2 właściwy minister mógł upoważnić podległe mu jednostki organizacyjne do udzielania zamówień przedsiębiorcom prywatnym, lecz jedynie w określonym ,przeciągu czasu” oraz do wysokości określonych sum.

Kierunek dyskryminacji podmiotów prywatnego sektora gospodarczego, wciąż istniejącego, choć bardzo ograniczonego w stosunku do realiów przedwojennych, znajdował kontynuację i utrwalenie w kolejnej ustawie z dnia 28 grudnia 1957 roku o dostawach, robotach i usługach na rzecz jednostek państwowych ${ }^{14}$. Odnośny akt prawny, analogicznie jak uchylona przez niego ustawa z 1948 roku, przewidywał jako zasadę udzielanie zamówień w kręgu państwowych jednostek

13 R. Szostak, Regulacja prawa zamówień..., s. 25.

14 Ustawa z dnia 28 grudnia 1957 roku o dostawach, robotach i usługach na rzecz jednostek państwowych, Dz.U. z 1957 r. Nr 3, poz. 7 ze zm.; dalej: ustawa z 1957 roku. 
organizacyjnych zobowiązanych do stosowania się do ustawy ${ }^{15}$. Wykonawcami dostaw, usług lub robót budowlanych miały być te spośród jednostek państwowych, które wykonywały działalność gospodarczą, w szczególności: przedsiębiorstwa państwowe, przedsiębiorstwa pod zarządem państwowym, spółki, w których państwo, instytucje lub przedsiębiorstwa państwowe posiadały ponad 50\% kapitału zakładowego. Na zasadach analogicznych jak wskazane podmioty, w kontekście możliwości uzyskiwania zamówień, traktowane były spółdzielnie, ale już nie rzemieślnicze spółdzielnie utworzone dla celów zaopatrzenia lub zbytu. Ta ostatnia grupa podmiotów była traktowana na równi z tak zwanymi jednostkami gospodarki nieuspołecznionej, dalece ograniczonymi w dostępie do zamówień od jednostek państwowych (art. 2 ust. 4). Gdy chodzi o takie ograniczenia, to ustawa z 1957 roku przewidywała możliwość udzielenia zamówienia rzemieślnikom, przedsiębiorstwom prywatnym lub innym osobom nie będącym jednostkami gospodarki uspołecznionej jedynie wtedy, gdy łączna wartość przedmiotu zamówienia nie przekraczała wyznaczonych, niskich progów wartości (na przykład 5 tysięcy zł przy dostawach; 60 tysięcy zł przy robotach budowlano-remontowych).

Do tego w niektórych przypadkach przewidywano fakultatywną „kontrolę społeczną" zamiaru powierzenia zamówienia podmiotowi niepaństwowemu (jednostce gospodarki nieuspołecznionej). Zgodnie z przepisem art. 5 ust. 1 taki zamiar powinien był być podany do wiadomości załogi jednostki udzielającej zamówienia poprzez wywieszenie ogłoszenia dotyczącego zamówienia oraz proponowanego wykonawcy, wzywającego członków załogi oraz innych zainteresowanych do zgłaszania ewentualnych zastrzeżeń. W razie ich zgłoszenia ostateczną decyzję w sprawie udzielenia zamówienia danemu podmiotowi, spoza kręgu państwowych jednostek organizacyjnych, miała podejmować właściwa rada robotnicza, a w razie jej braku kierownik jednostki zamawiającej.

Odnosząc się do innych aspektów treści ustaw z 1948 oraz z 1957 roku należy zwrócić uwagę na fragmentaryczność zawartych w nich regulacji. Wyrażało się to między innymi w obecności przepisów delegujących na różne organy administracji państwowej (w szczególności szczebla ministerialnego) kompetencje ${ }^{16}$ do normowania istotnych kwestii udzielania oraz wykonywania zamówień, w drodze aktów podustawowych, w tym aktów prawa wewnętrznego. Materią takich aktów miały być między innymi kwestie samych sposobów zawierania umów, udzielania zaliczek czy przyjmowania przedmiotu zamówienia ${ }^{17}$. Taki sposób regulowania udzielania i wykonywania zamówień państwowych, gdzie ramowej ustawie, nieodnoszącej się do wielu podstawowych kwestii dla umownych form działania administracji, towarzyszyły regulacje w drodze rozporządzeń czy aktów prawa

15 W ustawie z 1957 roku nie używano już określenia ,zamawiający”, obecnego jeszcze w treści poprzedniej ustawy z 1948 roku.

16 Zob. art. 6 ust. 2-4, art. 9 ustawy z 1947 roku oraz art. 3 ust. 3, art. 6 ust. 2, art. 9-10 ustawy z 1957 roku.

17 Zob. art. 6 ust. 2-4, art. 9 ustawy z 1948 roku; art. 9-10 ustawy z 1957 roku.

Studia nad Autorytaryzmem i Totalitaryzmem 43, nr 2, 2021

(C) for this edition by CNS 
wewnętrznego wiążących jednostki organizacyjne z poszczególnych resortów albo branż działalności gospodarczej ${ }^{18}$, utrzymywał się do lat osiemdziesiątych ${ }^{19}$.

W roku 1984 weszły w życie przepisy, w ramach których ustawowo nadano Radzie Ministrów uprawnienie do nakładania obowiązku przeprowadzenia postępowania przetargowego, w którym o zawarcie umowy mogły ubiegać się również jednostki gospodarki nieuspołecznionej. W przypadkach takich Rada Ministrów określała zasady i tryb przeprowadzenia takiego postępowania. Zamówienia rządowe były więc regulowane tak zwanymi uchwałami samoistnymi Rady Ministrów ${ }^{20}$. Uchwały te zostały zniesione rozporządzeniem Rady Ministrów z dnia 22 września 1987 roku w sprawie szczegółowego trybu i zasad zlecania zamówień rządowych ${ }^{21}$.

Zarysowując problem zamówień publicznych w PRL należy także zwrócić uwagę na wyłączenie z zakresu regulacji (względnie ograniczenia stosowania) przepisów o dostawach, usługach i robotach na rzecz jednostek państwowych do świadczeń pomiędzy jednostkami gospodarki uspołecznionej, w ramach realizacji państwowych planów gospodarczych ${ }^{22}$. Ta kwestia oraz inne wyłączenia stosowania odnośnych ustaw przesądzały o ich nieznacznej roli w normowaniu działań polegających na uzyskiwaniu potrzebnych świadczeń majątkowych przez zamawiających państwowych. W końcu należy pamiętać o charakterystycznej cesze dominacji instrumentów administracyjnoprawnych nad cywilnoprawnymi w regulacji prawnej procesów gospodarczych w ustroju gospodarki planowej. Wpływ tego stanu rzeczy na znaczenie umów w działalności państwowych jednostek organizacyjnych dobrze oddaje stwierdzenie R. Szostaka, zgodnie z którym

W ponadczterdziestoletnim okresie gospodarki nakazowo-rozdzielczej regulacje świadczeń zamawianych na cele publiczne funkcjonowały w rozproszeniu, na dodatek przepełnione były pierwiastkami administracyjnymi. Podstawowe bowiem znaczenie miały plany dyrektywne przesądzające o rodzajach i wielkości świadczeń, rozdzielniki administracyjne - wskazujące uprawnionych oraz cenniki urzędowe, natomiast umowa stanowiła jedynie niewiele znaczące dopełnienie ${ }^{23}$.

18 Zob. art. 6 ust. 2-3, art. 9 ust. 3 ustawy z 1948 roku; art. 1 ust. 2, art. 6 ust. 2, art. 11 ustawy z 1957 roku. Por. rozporządzenie ministra handlu wewnętrznego z dnia 17 marca 1958 roku w sprawie zasad i trybu udzielania zamówień na dostawy, roboty i usługi przez państwowe jednostki handlowe (Dz.U. z 1958 r. Nr 19, poz. 83 ze zm.).

19 H. Nowicki, Wprowadzenie do systemu zamówień publicznych, [w:] System zamówień publicznych w Polsce, red. J. Sadowy, Warszawa 2013, s. 18.

20 O. Rytel, Rozwój zamówień publicznych w Polsce, ,Zeszyty Naukowe Uniwersytetu Przyrodniczo-Humanistycznego w Siedlcach" 2012, nr 95, s. 510. Przykładem takiego aktu jest uchwała nr 8 Rady Ministrów z dnia 24 stycznia 1986 roku w sprawie zamówień rządowych na realizację zadań z zakresu rozwoju nauki i techniki, „Monitor Polski”, nr 6, poz. 37.

21 Rozporządzenie Rady Ministrów z dnia 22 września 1987 roku w sprawie szczegółowego trybu i zasad zlecania zamówień rządowych do 1990 roku oraz ich realizacji, Dz.U. z 1987 r. Nr 29, poz. 160 .

22 O. Rytel, op. cit., s. 508-509. Zob. art. 1 ust. 3 ustawy z 1948 roku oraz art. 11-12 ustawy z 1957 roku.

23 R. Szostak, Założenia treści prawa zamówien publicznych, „Prace Naukowe Uniwersytetu Ekonomicznego we Wrocławiu. Research Papers of Wrocław University of Economics” 2017, nr 497, s. 39.

Studia nad Autorytaryzmem i Totalitaryzmem 43, nr 2, 2021

(C) for this edition by CNS 
Dominacja administracyjnych form reglamentacji świadczeń na cele publiczne, w postaci skorelowanych z planami gospodarczymi rozdzielników i uzgodnień dostaw (robót) oraz rozmaitych urzędowych cenników w połączeniu z ustalanymi przez właściwe organy administracji szczegółowymi warunkami umów o charakterze normatywnym, w praktyce eliminowały swobodę kontraktową do tego stopnia, że umowa $\mathrm{w}$ obrocie $\mathrm{z}$ udziałem jednostek gospodarki uspołecznionej pełniła rolę przysłowiowego „listka figowego" 24 .

\section{Zakończenie}

W ramach powyższych rozważań wybranych zagadnień regulacji zamówień publicznych w PRL wyraźnie rysuje się motyw systemowej dyskryminacji potencjalnych wykonawców spoza sektora państwowego. Kwestia ograniczenia do jak najrzadszych sytuacji możliwości wykonywania zamówień państwowych przez prywatne podmioty gospodarcze stanowiła niewątpliwie jeden z naczelnych aspektów przedmiotowego ustawodawstwa. Ten stan rzeczy odpowiadał założeniom upaństwowionej, centralnie planowanej gospodarki, w ramach której to państwowe jednostki gospodarcze miały zaspokajać towarowo-usługowe potrzeby całego sektora państwowego. Oznaczało to, że, co do zasady, te same rodzajowo podmioty występowały po stronie zamawiających oraz wykonawców. Znamienna cechą przedstawianego w niniejszym artykule ustawodawstwa był duży stopień ogólności regulacji oraz jej fragmentaryczność. Ustawodawstwo to w bardzo niewielkim stopniu normowało - stanowiące dziś zasadniczy przedmiot regulacji prawa zamówień publicznych - kwestie rozwiązań proceduralnych w zakresie sposobów zawierania umów. Sposób dochodzenia do zawarcia umowy był natomiast $\mathrm{w}$ większym stopniu przedmiotem normowania aktów podustawowych. Biorąc pod uwagę, że odnośne przepisy przewidywały zawieranie umów między jednostkami gospodarki uspołecznionej, w tak zwanym trybie bezprzetargowym, można stwierdzić, że przepisy takie właściwie nie normowały kwestii ubiegania się o zamówienia, co potwierdza przekonanie o ich „fasadowości”. Tak skonstruowana regulacja nie mogła przyczyniać się w większym zakresie do osiągania uniwersalnego i pierwotnego celu leżącego u podstaw prawa zamówień publicznych, jakim jest efektywność (gospodarność) w wydatkowaniu publicznych środków finansowych. Wynikało to przede wszystkim ze szczątkowych możliwości wykorzystywania mechanizmu konkurencji, zasadniczo obcego gospodarce upaństwowionej.

Odtworzenie rynku zamówień publicznych jako istotnej części procesów gospodarczych w Polsce stało się możliwe dopiero wraz z transformacją ustrojową, w tym przechodzeniem do ustroju społecznej gospodarki rynkowej. Konsekwencją

24 R. Szostak, Regulacja prawa zamówień..., s. 26. 
tego procesu było uchwalenie w 1994 roku ustawy o zamówieniach publicznych ${ }^{25}$ opartej na zasadzie równego traktowania podmiotów gospodarczych, bez względu na pochodzenie ich kapitału, a także na zasadzie ochrony konkurencji.

\section{Bibliografia}

Burgi M., Die künftige Bedeutung der Freiheitsgrundrechte für staatliche Verteilungsentscheidungen, [w:] Wirtschaftsverfassung und Vergaberecht - Der Verfassungsrechtliche Rahmen der Auftrags- und Konzessionsvergabe, red. M. Bugenberg, P. Huber, R. Streinz, Stuttgart 2011.

Maurer H., Ogólne prawo administracyjne. Allgemeines Verwaltungsrecht, Wrocław 2003.

Nowicki H., Wprowadzenie do systemu zamówień publicznych, [w:] System zamówień publicznych w Polsce, red. J. Sadowy, Warszawa 2013.

Rytel O., Rozwój zamówień publicznych w Polsce, „Zeszyty Naukowe Uniwersytetu Przyrodniczo-Humanistycznego w Siedlcach" 2012, nr 95.

Szostak R., Regulacja prawa zamówień publicznych w Polsce w ujęciu historycznym, „Prawo Zamówień Publicznych. Kwartalnik” 2012, nr 4.

Szostak R., Zakres i struktura prawa zamówień publicznych, „Prawo Zamówień Publicznych. Kwartalnik" 2013, nr 4.

Szostak R., Założenia treści prawa zamówień publicznych, „Prace Naukowe Uniwersytetu Ekonomicznego we Wrocławiu. Research Papers of Wrocław University of Economics” 2017, nr 497. ze $\mathrm{zm}$

25 Ustawa z dnia 10 czerwca 1994 r. o zamówieniach publicznych, Dz. U. Nr 76, poz. 344, 